\title{
DETERMINATION OF THE RELEVANT MARKET AS A CRITERION OF ASSESSMENT OF CONCENTRATION EFFECTS IN THE PRACTICE OF ANTITRUST AUTHORITIES
}

\author{
DARIA KOSTECKA-JURCZYK*
}

\section{INTRODUCTION}

The purpose of the Regulation on the control of concentrations between undertakings is to maintain effective competition on the market and provide consumers with such benefits as low prices and high-quality goods, as well as a wide range of products, services and innovations. Mergers between competing undertakings or potential competitors on the same market eliminate competitive behaviours on this market, causing an increase of concentration, and may lead to increased or strengthened market power of the undertakings. Competition protection authorities have introduced a ban in an attempt to prevent concentrations, due to the fact that they lead to a significant impediment of effective competition and are unfavourable for consumers. They may cause, for example, a significant increase in the market power of the concentrated undertakings, and thus lead to an increase in prices. What is meant by the above is the ability of one or several undertakings to increase prices, limit production or choice, decrease the quality of goods and services, or otherwise influence the conditions of competition.

Therefore, regulations on concentrations are key tools for controlling the market's structure. An assessment of the impact of concentration on the market requires, most importantly, the determination of the relevant market on which the limitation, impediment or distortion of competition may take place. Determination of the relevant market is both the first and the most significant step in antitrust proceedings, because an entrepreneur's market position is always determined in relation to the relevant market.

It is important to determine the market so that in the next stage we can determine whether the aim or the result of the merger is limitation of competition, or if the merger reaches the turnover threshold, placing it under the jurisdiction of the national competition protection authority or the European Commission, or if it will result in achieving a dominant position which would interrupt competition on the given market. ${ }^{1}$

*PhD, LLM; Institute of Economics, Wroclaw University; dkj@prawo.uni.wroc.pl 
In the case of concentration, defining the market is significant insofar as it is a tool for assessing the anti-competition results of concentration.

This publication aims neither at a detailed discussion of the manner for determining a relevant market, nor of the tools used in this respect by competition protection authorities. Its purpose is to demonstrate the essence of determination of the relevant market in the control of concentrations in reference to the behaviors of undertakings falling under the scope of Art. 101 and 102 TFEU.

\section{DEFINITION OF THE RELEVANT MARKET}

'A market in competition law is the forum in which undertakings seek to sell or buy certain substitutable products or services. ${ }^{2}$ According to the definition set forth in the relevant European Commission notice ${ }^{3}$, every determination of the market has both an objective (commodity-based) and geographical dimension. According to the Commission's definition, the relevant commodity market comprises any commodities and/or services which, in the eyes of consumers, are substitutable or are close substitutes, based on their characteristics, price and function. The relevant geographical market constitutes an area within which given undertakings offer relevant commodities or services, and on which the conditions of competition are sufficiently uniform, and at the same time perceptibly different from those on neighbouring markets. ${ }^{4}$

The relevant market is also defined in the legal regulations of some EU member states. The definition provided by the Polish UOKiK (Office of Competition and Consumer Protection) is similar to the one formulated by the Commission. ${ }^{5}$ Both in its publications and in practice, the Commission additionally distinguishes a relevant time market and a market of entities.

The Commission determines the relevant market separately (anew) in each case. Therefore, there is no guarantee that the Commission will continue using the same definition of the market as was formulated in another case. In practice, the Commission has a strong tendency for using analyses and definitions of the market applied in previous decisions as a starting point in new cases.

A characteristic feature of the control of concentrations is that the legal analysis of transaction effects has a forward-looking nature. It does not analyze the current state, but examines the future state (effects in the sphere of competition are analyzed in reference to the future concentration in

\footnotetext{
${ }^{1}$ See T Skoczny, Ustawa o ochronie konkurencji i konsumentów. Komentarz (CH Beck 2009) 208-209.

2 T Rosenthal, S Thomas, European Merger Control (CH Beck 2010) 89.

${ }^{3}$ Commission Notice on the definition of relevant market for the purposes of the Community competition law [1997] OJ C 372/5.

${ }^{4}$ Ch Bangard, D Möller, A Raimann, N Szadkowski, U Dubejko, Instrumenty ekonomiczne w prawie konkurencji (UOKiK 2007) 61.

${ }^{5}$ Article 4 (9) Act on Competition and Consumer Protection of 16 February 2007, Journal of Laws 2007, no 50, item 331 (as amended).
} 
future, hypothetical conditions that do not exist as at the moment of the analysis).

In contrast, the retrospective definition of the market used in the analysis of behaviors of undertakings in the light of Art. 101 and 102 TFEU refers to the definition of the market relevant for the period in which such behaviors occurred. Here the earlier period (before issuing the decision) is taken into account. Thus, in the context of Art. 102 TFEU the market may be determined more narrowly or more broadly than in proceedings concerning the control of concentrations.

The latter issue concerns the institutional aspects of collusion. Whereas decisions regarding violations of Art. 101 and 102 TFEU are to a significant degree controlled by the General Court (GC) and the European Court of Justice (ECJ), in concentration cases the courts less often review Commission decisions, as demonstrated in the significantly lower number of decisions issued by those courts.

Proceedings related to control of concentrations take place under strictly-appointed time limits. As a result, the prospect of conducting proceedings before the General Court in order to change a Commission decision is often impractical for the merging parties. Practical considerations encourage the parties to a transaction to communicate with the Commission in the course of proceedings rather than to consider lengthy and costly court proceedings.

This effect is further reinforced by the practice of the General Court, as it hardly ever challenges the Commission's economic analyses. Moreover, a significant part of the Court's practice as regards concentrations is related solely to decisions of the Commission and does not include any rulings in which the Court pronounces them flawed. In this situation the ECJ's practical role in development of the substantive law of control of concentrations in the light of the Regulation 139/04 is rather limited.

\section{TOOLS USED TO DETERMINE THE RELEVANT MARKET}

In order to determine the relevant market, three main factors are considered. The first one is based on the identification of a product appropriate (useful, significant) for consumers. The second one requires the determination of the relevant geographical market, also from the point of view of the consumer. The last factor is the determination of whether there are entrepreneurs who could enter the given market in the future.

In the case of concentrations, the economic approach is presently used most frequently for market analysis; this results from the definition of the market as set forth in the Commission's notice in which both qualitative and quantitative methods are applied ${ }^{6}$. The first type serves the purpose of assessing the substitutability of products or services based on their characteristic features (from the point of view of the consumer). The latter

\footnotetext{
${ }^{6}$ Van Bael \& Bellis, Competition Law of the European Community (Kluwer Law International 2005) 782-791.
} 
additionally enables the assessment of the degree of the products' substitutability. ${ }^{7}$ What follows is a presentation of the Commission's approach to the determination of the commodity market and geographical market in selected decisions, as well as the instruments used by the Commission.

\section{A. The relevant product market}

Determination of the market is based on economic analyses of the flexibility of supply and demand, as well as on market research. For example, in the United Brands case $^{8}$, the European Court of Justice used mixed flexibility of demand research, whose aim was to measure whether the price of one product influences the demand for other products. In another example, the key criteria in the ABB Daimler-Benz case were the properties, price and assumed way of using the product. ${ }^{9}$

According to the Commission's notice on the relevant market definition $^{10}$, the assessment of the substitutability of demand entails the determination of the range of products perceived by the consumer as substitutes. One of the methods used for such a determination is an experiment based on suppositions, assuming a hypothetical, small but constant change in the relative prices and assessing presumable reactions to such an increase. Use of the definition of the market is focused on prices and on substitutability of demand, resulting from small but constant changes in relative prices.

When determining the relevant product market, the Commission particularly takes into account the differences in prices between comparable commodities, as well as price elasticity of demand and mixed flexibility of demand. ${ }^{11}$

Testing the mixed flexibility of demand by the European Commission is based on the SSNIP ${ }^{12}$ test, which allows for the establishment of the degree to which demand for a given commodity will change if the price of another commodity (a substitute) changes. The test relates to a relatively small but significant and non-transitory increase in prices. It is used in order to determine whether consumers will be prone to switch to a different product if faced with such an increase in the price (usually this increase is 5-10\%).

According to p. 17 of the Notice, the question must be answered of whether consumers - in response to a hypothetically small (5-10\%) but non-

\footnotetext{
${ }^{7}$ Ch Bangard, D Möller, A Raimann, N Szadkowski, U Dubejko (n 4) 65.

${ }^{8}$ Case 27/76 United Brands [1978] ECR I-207.

${ }^{9}$ ABB/Daimler-Benz (Case IV/M.580) Commission Decision 97/25/EC [1997] OJ L11/1.

${ }^{10}$ Commission Notice on the definition of relevant market (n 3).

11 See Nestlé/Perrier (Case IV/M.190) Commission Decision 92/553/EEC [1992] OJ L356/1, para 13; Airtours/First Choice, (Case IV/M.1524) Commission Decision 2000/276/EC [2000] OJ L93/1 (it was annulled in the judgment ECJ Airtours v Commission [2002] ECR II-2585); case Airtours v Commission [2002] ECR II-2585, para 41; UPMKymmne/Haindl (Case M.2498) Commission Decision 2002/737/EC [2002] OJ L233/38, para 21; Nestlé/Perrier (Case IV/M.190) Commission Decision 92/553/EEC [1992] OJ L356/1, para 16; Tetra Pack/Alfa Laval (Case IV/M.68) Commission Decision 91/535/EEC [1991] OJ L290/35 par 2.1.(v); Du Point/ICI (Case IV/ M.214) Commission Decision 93/9/EEC [1993] OJ L7/13, para 28.

12 Small Significant Non-transitory Increase in Price.
} 
transitory increase in the relative prices of goods in the considered geographical areas - will switch immediately to available substitutes or services of providers located in another area. If the substitution is enough to prevent profit generation from the increase in prices due to the decrease in sales, additional substitutes and areas are included in the relevant market. This will be done until the whole range of products and geographic areas will be such that a small, non-transitory increase in prices is no longer profitable.

Generally speaking, the SSNIP test should be used in situations where a monopolist establishes prices at such a high level that any further increase in those prices would not be profitable. Otherwise, the SSNIP test would lead to an underestimation of the monopolist's market power, because it might suggest that no increase in prices would be profitable and would therefore lead one to define the market too broadly (this problem is commonly described as the Cellophane Fallacy).

In this respect, the definition of the market in the case of mergers will differ slightly from the one applied in behavioural cases. Here the Cellophane Fallacy will not occur often, because most mergers take place on markets where competition is present and prices are below the monopoly level. As a result, the SSNIP test will usually be the Commission's basic tool used for establishment of the relevant market in mergers. Apart from the SSNIP test, the Commission also uses other qualitative factors, such as consumer preferences, changes in costs, data regarding changes of demand in the future, as well as the structure of demand. This is particularly visible in the case of a merger of two cooperating Danish farmers, where the Commission indicated that pork and beef were two separate product markets. $^{13}$

Among other qualitative factors which the Commission examines when determining the market, one may distinguish characteristic features of a product and the expected manner of using various goods or services. ${ }^{14}$ Competition may be estimated in relation to the characteristic features of the given product which enable satisfaction of consumers' inflexible needs, while the distinguishable features of the given product significantly limit the possibility of substitution. ${ }^{15}$

In cases where concentration gives rise to problems related to competition in connection with supply of goods or services, the Commission will thoroughly examine the effects of transactions, including demand (sales market). While determining the relevant market from the point of view of

13 Danish Crown (Case IV/M.1313) Commission Decision 2000/42/EC [2000] OJ L20/1; AOL/Time Warner (Case M.1845) Commission Decision 2001/718/EC [2001] OJ L268/28, paras 17-21.

14 Aérospariale-Alenia/de Havilland (Case IV/M.53) Commission Decision 91/619/EEC [1991] OJ L334/42, para 8; Nestlé/Perrier (Case IV/M.190) Commission Decision 92/553/EEC [1992] OJ L356/1; Guinness/Grand Metropolitan (Case IV/M.938) Commission Decision 98/602/EC [1998] OJ L288/24, para 10; Telia/Telenor Case (IV/M.1439) Commission Decision 2001/98/EC [2001] OJ L40/1, para 94; HoffmannLaRoche/Boehringer Mannheim (Case IV/M. 950) Commission Decision 98/526/EC [1998] OJ L234/14, para 11.

${ }^{15}$ Case 6/72 Continental Can v Commission [1973] ECR I-32. 
demand, the crucial question is whether suppliers use various sales channels as exchangeable and substitutable.

In the sphere of competition, problems may originate from the power of purchasers insofar as the concentration gives rise to such or strengthens it. In effect, it may contribute to impeding competition on the demand side. However, the power of purchasers may also be perceived as pro-competitive if it contributes to lowering costs of entry without impeding competition in the downstream market or limiting total production. In such cases it is the Commission's opinion that better sales conditions may be transferred by purchasers to consumers.

Obviously, the same transaction may sometimes raise concerns both in the market of supply and the market of demand. This particularly concerns concentrations in the market of retail sale of consumer goods and procurement markets. An example of such accumulated effects was the Rewe/Meinl ${ }^{16}$ case, where the Commission found that concentration disrupted competition in two different markets: distribution and procurement.

\section{B. The relevant geographical market}

Generally speaking, a geographical market is a territory where objective conditions of competition used for specific products must be the same for all merchants. ${ }^{17}$ Examples of conditions breaching the geographic scope of the market include: costs of transport relative to the product price, national technical standards and national preferences. In any proceedings regarding concentrations, the purpose of defining the geographic market is the determination of an area or areas on which the unit upon merger might encounter actual or potential competition.

In order to define a geographical market in cases of mergers, as in the case of determining the commodity market, one must examine other factors connected with demand and supply. When analyzing the demand part of the market one must pay particular attention to such factors as diversification of orders in particular geographic areas or consumer preferences.

Substitutability of demand plays a significant role in defining the market by the Commission, although when defining the market in the case of mergers, the Commission more often takes into account flexibility of supply.

Art. 9 (7) of the Regulation on the control of concentrations between undertakings contains a catalogue of factors which may influence determination of the relevant geographical market by the Commission. They include the core and characteristic features of products or services, the existence of barriers of entry into the market, consumer preferences, significant differences in market shares between neighboring areas and regional differences in prices, entry barriers and costs of transport. Trade flows may also serve as an indicator of the range of the geographic market. ${ }^{18}$ A factor describing a separate market might also be the intensity

\footnotetext{
${ }^{16}$ Rewe/Meinl (Case IV/M.1221) Commission Decision 1999/674/EC [1999] OJ L274/1.

${ }^{17}$ Case 27/76 United Brands Company v Commission [1978] ECR I-207, para 44.

18 UPM-Kymmne/Haindl (Case M.2498) Commission Decision 2002/737/EC [2002] OJ

L233/38, paras 25-30; Price Waterhouse/Coopers\&Lybrsand (Case IV/ M.1016)
} 
and structure of competition, if it differs significantly from other areas. As far as the Commission's decisions are concerned, language barriers also play a key role. They are particularly significant in sectors connected with media, broadcasting of television or radio programs and communications. For example, in the Providence/Carlyle/UPC Sweden case the Commission considered the wholesale market of program broadcasting services as a national market due to the language homogeneity of the examined area. ${ }^{19}$

The Commission often bases its assessments on price differences, although these do not constitute proof of existence of separate geographic markets. They only reflect differences in the flexibility of demand, since, for example, consumers in certain member states are wealthier and may pay more for the same goods. Yet, as the Commission's decision in the Volvo/Scania case ${ }^{20}$ shows, the cause of price diversification is the behaviour of producers eager to take advantage of consumers' diverse needs in particular countries. If technical requirements in particular countries were standardized, parallel trade could develop, and price differences would be eliminated over a shorter period of time.

The rules applied in the method for defining the market used in relation to the market of goods and services are similar. Very recent decisions issued in cases of mergers confirm that the Commission more frequently deals with newly-created markets. The definition of the market must deal with such technical developments as the formation of an electronic goods market or a market for Internet services. However, analysis of the decision practice of the Commission provides only limited guidelines in these cases. One of the problems when applying the regulations on competition in the 'new economy' is the application of the generally accepted rules for defining a market. The purpose of the SSNIP test is to establish the flexibility of demand in a short period of time. However, the markets for highlydeveloped technologies are characterized by dynamic competition, under which particular products are endangered by newly-created ones. The hidden assumption of the SSNIP test is that products are homogeneous and rivals engage in price competition. Focusing on a hypothetical increase in prices rather than the restrictions in competition resulting from the innovativeness of the products may lead to an overly-narrow definition of the market in branches of industries characterized by high competition dynamics. Defining a relevant market in the industries of highly-advanced technologies is particularly problematic in cases concerning concentration, when the two merging parties may begin production of innovative, previously non-existent goods.

In the light of Art. 2 (2) and (3) of Regulation 139/04, a geographically relevant market must include a significant part of the internal market. A certain level of turnover must be achieved in order for this

Commission Decision 1999/152/EC [1999] OJ L050/27, para 62; Volvo/Scania (Case M.1672) Commission Decision 2001/403/EC [2001] OJ L143/74, paras 61-63.

${ }^{19}$ Providence/ Carlyle/UPC Sweden (Case COMP/M.4217) Commission Decision [2006] OJ L144/15.

${ }^{20}$ Volvo/Scania (n 18), paras 48-58. 
criterion to be met. In practice, this requirement is met in most cases . Smaller local markets may constitute a significant part of the internal market through the chain of substitution. After the relevant market has been determined, in order to identify the impediment of competition by the merged undertaking following the concentration, the Commission will analyze such a market as regards the potential effects resulting from the concentration. The Commission must differentiate between horizontal, vertical and conglomerate effects.

\section{ASSESSMENT OF MERGER EFFECTS}

An appropriate determination of the market is a crucial preliminary condition of the merger impact assessment for the competition. ${ }^{21}$ The economic judgment of the merger impact on the processes of competition requires definition of the relevant market in order to assess whether SIEC will occur, in particular by gaining or strengthening a dominant position. The definition of the market is a key factor, since it allows the Commission to acquire specific information regarding the market power which the merged units will possess; only this information allows for an assessment of the impact the concentration will have on the market, as well as for conducting this assessment from the point of view of competition. The main purpose of the market definition is to comprehensively determine the immediate limitations to competition imposed by the merged units and to establish whether problems may occur in terms of competition ${ }^{22}$.

The impacts of mergers vary depending on their type ${ }^{23}$. Horizontal mergers (for competition on the same level of the production or distribution chain), vertical mergers (on a lower or higher level of the production or distribution chain) or conglomerate mergers (on markets not connected with the one on which the transaction is being carried out) lead to differing results.

Horizontal mergers may remove significant competitive barriers on one or more undertakings on the market, thus strengthening their market power or leading to price increases. In general, this may happen as a result of obtaining or strengthening the dominant position of an undertaking, whose market share will be much greater than its competitors after the merger. This also relates to a non-collusive oligopoly, i.e. a situation in which, following the merger, the undertakings present on the market will be able to use their market power and lead to an increase in prices even if the probability of coordination between the undertakings is small and individually they are not dominant.

\footnotetext{
${ }^{21}$ S Bishop, '(Fore)closing the Gap: the Commission's Draft Non-Horizontal Merger Guidelined' (2008) 1 European Competition Law Review 1; A Heimler, 'Was the Change of the Test for Merger Control in Europe Justyfied? An Assessment (Four Years After the Introduction of SIEC)' (2008) 4 European Competition Journal 85.

${ }^{22}$ A Kaczorowska, European Union Law (Routledge 2011) 913-914.

${ }^{23}$ A Jurkowska-Gomułka, T Skoczny, Wspólne reguly konkurencji Unii Europejskiej (Instytut Wydawniczy Euro Prawo 2010) 151-171; R Wish, Competition Law (Oxford 2010) 849-871.
} 
Some mergers may lead to SIEC by increasing the probability that companies will be able to behave in a coordinated manner without entering into agreements or resorting to an agreed practice inconsistent with Art. 101 TFEU. Such coordination may concern prices, but may also appear in relation to levels of production, increases in productivity, allocation of markets or contracts awarded in tenders. Usually, coordination is more probable if it is relatively easy to achieve a mutual agreement ${ }^{24}$.

Non-horizontal mergers, e.g. vertical ones, usually result in a lesser probability of a significant impediment of competition than horizontal ones. Not only do they not cause losses in terms of direct competition between the parties merging on the same market, but they can even strengthen their effectiveness, especially through integrating complementary areas of operation and limiting transaction costs. They can lead to lower prices and higher production, or to expansion of the range of products offered to clients. However, non-horizontal mergers may be harmful for competition if they change the ability and motivation of the merged undertaking and its competitors in a way which could be harmful for consumers. The Commission believes that (similarly to horizontal mergers) non-horizontal mergers should be reviewed in respect of possible coordinated and noncoordinated effects. Non-coordinated effects may appear when a merger leads to the exclusion of competitors. Coordinated effects, on the other hand, take place when a merger enables undertakers to act in a coordinated manner or if it facilitates such coordination. The Commission takes into account possible results of the merger, which at the same time constitute a part of the assessment of the given merger ${ }^{25}$.

Coordinated effects take place via changes in the nature of competition, as a result of which undertakings are more prone to coordination and price increases. The harm may appear on particular markets, usually when the undertakings operate on closely-related markets (e.g. of complimentary products or products aimed at the same group of clients and used for the same purpose). When assessing the vertical effects on the markets, the Commission additionally analyses both potential anticompetitive and pro-competitive effects resulting from the confirmed increase of effectiveness.

A conglomerate merger, on the other hand, may lead to the effect of exclusion, for example through allowing the merged undertaking to carry out exclusive practices such as package deals. Such mergers may also result in coordinated effects, such as limiting the number of effective competitors.

\section{CONCLUSiOnS}

Determination of the relevant market is an instrument allowing for the assessment of competitive relations and their borders on the market. An

\footnotetext{
${ }^{24}$ A Jones, EU Competition Law, Text, Cases and Materials (Oxford 2011) 915-941.
}

${ }^{25} \mathrm{~J}$ Faul, A Nikpay, The EC Law of Competition (Oxford 2007) 479-495. 
analytical framework is formed together with the definition of the relevant market, being a basis for the assessment of current and potential competition, as well as a facilitator of this assessment. Determination of the market has a crucial influence on the assessment of a given case and, thus, on the acceptance or rejection of a merger.

As indicated above, the Commission determines the relevant market separately in each case. Analysis of each concentration requires a fresh examination of the conditions of competition, including determination of the relevant market.

In practice, the Commission uses decisions issued in previous cases, checking in each new case whether there exist grounds for determining the relevant market in a way different than in past decisions. Competition analysis focuses on examining whether competition-related problems will increase after the transaction.

A key feature of cases related to concentrations is that the legal analysis of the transaction effects has a forward-looking nature. It does not analyze the current state but examines the future state (effects in the sphere of competition are analyzed in reference to the future concentration in future, hypothetical conditions that do not exist at the moment of the analysis). In contrast, the retrospective definition of the market used in the analysis of behaviors of undertakings in the light of Art. 101 and 102 TFEU refers to the definition of the market relevant for the period in which such behaviors occurred. Here, the earlier period (before issuing the decision) is taken into account. Thus, in the context of Art. 102 TFEU the market may be determined far more narrowly or more broadly than in proceedings related to review of concentrations. 